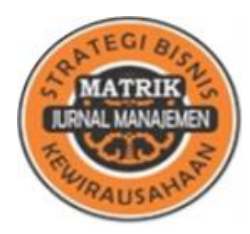

P-ISSN : 1978-2853 E-ISSN : 2302-8890

\section{MATRIK: JURNAL MANAJEMEN, STRATEGI BISNIS DAN KEWIRAUSAHAAN}

Homepage: https://ojs.unud.ac.id/index.php/jmbk/index

Vol. 13 No. 1, Februari 2019,96-107

\title{
MODAL, TINGKAT LIKUIDITAS BANK, NPL DAN PERTUMBUHAN KREDIT PERBANKAN INDONESIA
}

\author{
Rahmat Setiawan ${ }^{1)}$,Ahmad Aziz Putra Pratama ${ }^{2)}$ \\ ${ }^{1,2)}$ Fakultas Ekonomi dan Bisnis, Universitas Airlangga, Surabaya \\ email: rahmatsetiawan@feb.unair.ac.id
}

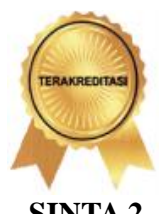

DOI : https://doi.org/10.24843/MATRIK:JMBK.2019.v13.i01.p10

\begin{abstract}
ABSTRAK
Tujuan dari penelitian ini adalah untuk menguji pengaruh modal bank terhadap pertumbuhan kredit dengan moderasi tingkat likuiditas dan kualitas kredit perusahaan perbankan yang terdaftar di Bursa Efek Indonesia (BEI). Penelitian ini menggunakan model regresi linier berganda dan Moderated Regression Analysis (MRA). Data diperoleh dari laporan keuangan perusahaan yang diterbitkan pada periode 2010-2016. Variabel dependen dalam penelitian ini adalah pertumbuhan kredit yang diproksi dengan Pertumbuhan Kredit Bersih. Variabel independen menggunakan modal bank diproksi dengan Capital Adequacy Ratio (CAR). Variabel moderasi dalam penelitian ini menggunakan tingkat likuiditas yang diproksi dengan rasio likuiditas dan kualitas kredit yang diproksi dengan Non Performing Loan (NPL). Selain itu, variabel pengendali dalam penelitian ini adalah ukuran perusahaan yang diproksikan dengan logaritma total aset. Hasil penelitian menunjukkan bahwa modal bank berpengaruh positif signifikan terhadap pertumbuhan kredit, sedangkan rasio likuiditas memperkuat pengaruh positif modal bank terhadap pertumbuhan kredit dan kredit macet memitigasi dampak positif modal bank terhadap pertumbuhan kredit

Kata kunci: capital adequacy ratio, ukuran perusahaan, liquidity ratio, pertumbuhan kredit bersih, non performing loan
\end{abstract}

\section{CAPITAL, LEVEL OF LIQUIDITY, NPLAND CREDIT GROWTH OF INDONESIAN BANKS}

\begin{abstract}
The purpose of this research is to examine the effect of bank capital on lending growth with moderation of liquidity level and credit quality of banking companies listed in Indonesia Stock Exchange (IDX). This study used multiple linear regression model and Moderated Regression Analysis (MRA). Data obtained from the company's financial report published in 2010-2016 period. Dependent variable in this research is lending growth proxied with Net Loans Growth. Independent variable used bank capital proxied with Capital Adequacy Ratio (CAR). Moderating variables in this research used liquidity level proxied with liquidity ratio and credit quality proxied with non performing loan (NPL). In addition, controlling variable in this study is firm size proxied with logarithm of total assets. The results showed that bank capital has significant positive effect on lending growth, while the liquidity ratio strengthens positive effect of bank capital on lending growth and non performing loan mitigates positive effect of bank capital on lending growth.
\end{abstract}

Keywords: capital adequacy ratio, firm size, liquidity ratio, net loans growth, non performing loan.

\section{PENDAHULUAN}

Perbankan merupakan institusi yang memiliki peran penting dalam membangun perekonomian negara (Kasmir, 2014:2). Hampir setiap transaksi keuangan harian yang dilakukan oleh masyarakat akan melibatkan peran bank. Bank memiliki peran penting bagi negara dalam memperlancar lalu-lintas finansial yang berdampak pada pertumbuhan ekonomi (Hasibuan, 2015:3). Bank menjadi tempat berbagai transaksi seperti menyimpan uang, investasi, transaksi pembayaran, transfer uang atau kegiatan penagihan (Kasmir, 2014:2).

Bank memiliki peran penting terhadap pertumbuhan ekonomi suatu negara. Kemajuan negara dapat dilihat dari kemajuan sistem perbankannya. Sebagian besar sektor yang dalam hal kaitannya dengan aktivitas finansial akan memerlukan jasa bank. Dunia global dan era 
kemajuan informasi dan teknologi tidak akan bisa lepas dari dunia perbankan karena berbagai aktivitas keuangan dan sosial membutuhkan lembaga yang memberikan jasa dalam memperlancar lalu-lintas keuangan.

Latumaerissa (2014:120) menjelaskan bahwa sektor perkreditan memiliki peran penting dalam kegiatan operasional suatu bank. Sumber penghasilan terbesar sebuah usaha bank berasal dari kontribusi banyaknya jumlah pemberian kredit yang tersalurkan. Bank di Indonesia masih menggunakan sektor bisnis perkreditan sebagai sumber utama penghasilan. Nilai margin pendapatan yang baik dapat diperoleh melalui pengelolaan manajemen dengan efektif dan efisien. Efektif berkaitan dengan ketepatan waktu sedangkan efisien berfokus pada meminimalisir biaya dalam mencapai suatu target optimal (Veithzal, 2012:197). Sebagai lembaga intermediary, bank harus mampu mengelola ketersediaan modal dan aset likuid yang dimiliki agar tidak terjadi kekurangan dana dalam menjalankan kegiatan bisnisnya. Kecukupan modal dan tingkat likuiditas bank menjadi perhatian penting karena akan berpengaruh terhadap kegiatan operasional suatu bank (Riyadi, 2006:22).

Bank yang sehat dilihat dari tingkat likuiditas yang terpelihara dengan secara efektif, tercukupinya modal dan kualitas kredit yang tersalurkan dengan baik. Bank yang terjaga kondisi likuiditasnya memiliki aset lancar yang cukup sehingga dapat memenuhi secara cepat penarikan dana dari deposan dan mampu menyediakan dana ketika terdapat permintaan kredit oleh debitur. Pengalokasian dana yang tepat, sehat dan profitable menjadi salah satu sumber pendapatan optimal bank dengan rendahnya tingkat kredit yang tidak tersalurkan dengan baik (non performing loan).

Nasabah yang memperoleh kredit bank tidak semuanya dapat mengembalikan utang dan bunganya tepat waktu. Realitas pada praktik lapangan selalu terdapat nasabah wanprestasi. Di pihak perbankan, nasabah yang tidak dapat membayar tepat waktu akan digolongkan menjadi kredit bermasalah dan akhirnya menjadi kredit macet. Kredit macet terjadi ketika utang tidak dapat dilunasi sehingga penyelesaiannya membutuhkan pihak ketiga atau melakukan eksekusi collateralnya (Supramono, 2009:268). Kredit macet tergolong salah satu kredit bermasalah yang akan menurunkan tingkat kualitas kredit yang diukur menggunakan rasio non performing loan (NPL). Menurut Ismail (2016:124) semakin kecil rasio NPL, semakin bagus kualitas kredit yang diberikan dan semakin kecil risiko tidak tertagihnya jumlah pinjaman yang disalurkan. Bank Indonesia mengeluarkan regulasi bahwa NPL tidak boleh di atas $5 \%$.

Bank dikatakan sebagai bank sehat apabila berhasil memenuhi persyaratan Bank Indonesia (Pandia, 2012:3). Bank memerlukan persediaan dana dalam menjalankan operasional bisnisnya. Fluktuasi persediaan dana bergantung pada berubahnya permintaan kredit dan simpanan deposan. Gerak perekonomian memengaruhi jumlah deposit dan penyaluran kredit. Manajemen perencanaan likuiditas salah satu fokus utama dilakukan dalam rangka menjaga kestabilan ketersediaan dana. Masalah likuiditas timbul bila terjadi pengaliran kredit yang berlebihan yang diiringi oleh tidak stabilnya liabilitas (Darmawi, 2014:57).

Peraturan Bank Indonesia menetapkan rasio kecukupan modal sebesar 8\%. Kecukupan modal menilai ketahanan bank terhadap risiko kredit. Semakin besar rasio CAR maka bank akan lebih mampu untuk mengatasi risiko kredit mereka sehingga akan meningkatkan kemampuan bank dalam menyalurkan kredit. Selain pengelolaan modal, tingkat likuiditas juga sebagai landasan dalam penentuan kesehatan bank. Likuiditas didefinisikan sebagai kompetensi bank dalam mendanai bertambahnya aset dan melunasi kewajibannya dengan tidak menimbulkan kerugian yang besar (Pandia, 2012:112). Salah satu pengukuran yang digunakan adalah dengan menerapkan rasio aset lancar dibanding dengan total aset sebagai pengukuran dasar. Semakin tinggi rasio ini maka semakin besar proporsi aset lancar yang dapat dijadikan sebagai dasar kemampuan bank dalam menyediakan dana ketika terdapat penarikan dana oleh nasabah dan mampu memberikan dana ketika terdapat permintaan kredit oleh debitur.

Fungsi likuiditas bagi bank secara umum biasanya digunakan guna menjalankan transaksi operasional bisnis harian bank, menyediakan kebutuhan dana ketika dalam keadaan mendesak serta memenuhi permintaan debitur terkait dengan pemberian kredit (Veithzal, 2012:147). Jika persyaratan dan ketentuan regulasi tidak dipenuhi dengan baik maka Bank Indonesia selaku bank sentral akan mengkategorikan bank bermasalah tersebut ke dalam perhatian dan pengawasan khusus (Hasibuan, 2015:65).

Pada saat krisis, perbankan Indonesia mengalami penurunan permodalan dan tingkat likuiditas. Hal tersebut dikarenakan terdapat penurunan aset dalam jumlah besar sehingga kualitas aset yang dimiliki menjadi rendah yang menyebabkan 
munculnya kerugian investasi. Penelitian Kim dan Sohn (2017)menjelaskan bahwa dalam kondisi krisis, bank akan lebih memilih menerapkan strategi bertahan (defensive) dengan cara mengurangi jumlah kredit yang diberikan atau tidak memberikan penyaluran kredit sama sekali. Tingginya penyaluran kredit pada saat krisis akan menaikkan aset yang lebih berisiko sehingga bank harus memperkuat modal dan memperbaiki likuiditasnya. Dengan adanya modal bank dan tingkat likuiditas yang dikelola dengan baik mencerminkan stabilnya permodalan dan rendahnya risiko yang dimiliki perbankan. Semakin besar modal dan tingkat likuiditas yang dimiliki bank, semakin tinggi kompetensi bank dalam memberikan penawaran kredit dalam jumlah yang lebih banyak.

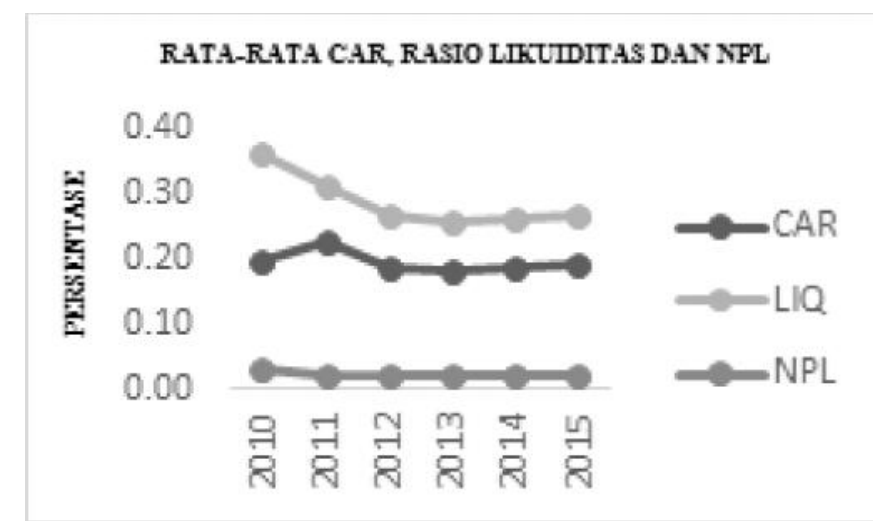

\section{Gambar 1. Rata-Rata CAR, Tingkat Likuiditas Bank dan NPL Perbankan Periode 2010-2015.}

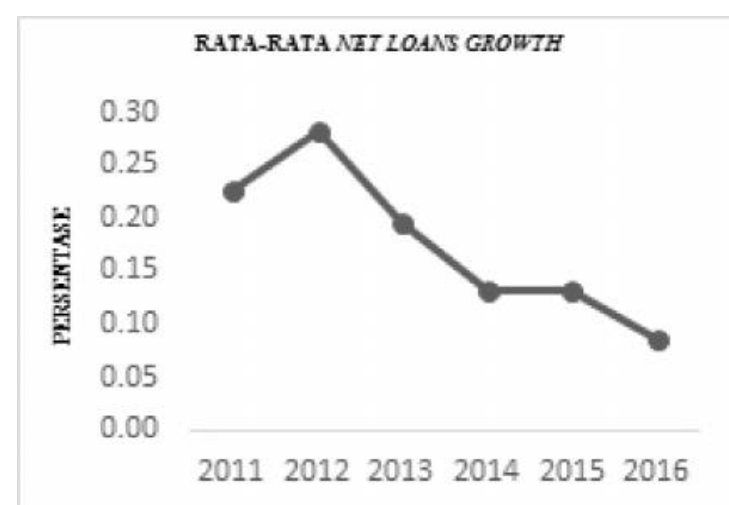

\section{Gambar 2. Persentase Rata-Rata Net Loans Growth Perbankan di Indonesia Periode 2011-2016}

Grafik pada Gambar 1. menunjukkan bahwa fluktuasi CAR selalu diikuti dengan pergerakan likuiditas dan kualitas kredit yang hampir sejajar. Fluktuasi NPL pada periode 2010-2015 berada di bawah $5 \%$. Pergerakan ketiga variabel tersebut selalu berjalan beriringan di setiap periode waktu. Pergerakan CAR pada periode sebelumnya mempengaruhi jumlah pertumbuhan kredit yang disalurkan. Hal ini dibuktikan dengan pergerakan CAR memiliki fluktuasi yang searah terhadap pertumbuhan kredit perbankan pada periode berikutnya.

Semakin tinggi modal bank semakin besar peningkatan jumlah kredit karena mampu mengemban risiko dari tingginya investasi pada aset berisiko. Likuiditas bank memperkuat pengaruh positif modal bank terhadap pertumbuhan kredit.Bank yang mengelola tingkat likuiditasnya dengan baik akan memiliki kemampuan menyalurkan kredit dalam jumlah yang lebih banyak karena bank memiliki dana likuid yang besar sehingga lebih mampu memenuhi permintaan kredit dari nasabah (debitur). Selain itu, NPL memperlemah pengaruh positif modal bank terhadap pertumbuhan kredit.Bank yang memiliki modal yang tinggi akan menjadi rendah tingkat penyaluran pinjamannya dikarenakan tingginya kredit bermasalah sehingga bank lebih cenderung untuk menahan jumlah kredit yang disalurkan. 
Penelitian sebelumnya hanya meneliti tentang pengaruh modal bank terhadap pertumbuhan kredit. Penelitian Kim dan Sohn (2017), Berrospide dan Edge (2010), Gambacorta dan Mistrulli (2004), Satria dan Subegti (2010) serta Meydianawathi (2007) berpendapat bahwa modal bank memiliki pengaruh positif signifikan terhadap jumlah kredit yang disalurkan. Hasil penelitian Moussa dan Chedia (2016) membuktikan bahwa likuiditas aset tidak berpengaruh signifikan terhadap pertumbuhan kredit di negara Tunisia. Penelitian lain oleh Yuwono dan Meiranto (2012), Dharma (2015) dan Sania (2016) menunjukkan bahwa NPL memiliki pengaruh tidak signifikan terhadap peningkatan kredit.

Sedikit sekali riset yang meneliti tentang tingkat likuiditas bank dan non performing loan sebagai variabel yang memoderasi pengaruh modal bank terhadap pertumbuhan kredit. Padahal peran likuiditas sangatlah penting dalam menjaga kelancaran kegiatan operasional bisnis perbankan dan non performing loan menggambarkan kualitas kredit yang disalurkan oleh bank.

Berdasarkan fenomena dan permasalahan tersebut, sangat penting dan menarik untuk dilakukan penelitian dalam menguji pengaruh modal bank terhadap pertumbuhan kredit dengan dimoderasi oleh tingkat likuiditas dan non performing loan.

Bank merupakan bagian instrumen dari perbankan. Menurut Ismail (2016:9) bank termasuk dalam lembaga keuangan dengan fungsi intermediary sebagai perantara pihak yang membutuhkan dana (lack of fund) dan pihak yang memiliki kelebihan dana (surplus of fund). Bank adalah salah satu lembaga finansial yang operasional bisnisnya menghimpun dana dari pihak ketiga (masyarakat) dalam wadah simpanan bank dan memberikannya kembali kepada pihak yang membutuhkan dalam bentuk kredit/bentuk lainnya guna memperlancar arus perekonomian dan menaikkan kesejahteraan rakyat.

Kredit merupakan pemberian dana dari pihak kelebihan dana kepada pihak yang membutuhkan dana atas dasar kepercayaan masing-masing kedua belah pihak Ismail (2016:93). Fungsi kredit memberikan pelayanan kepada masyarakat (yang membutuhkan dana) dalam memenuhi kebutuhan dan meningkatkan sektor bisnis (Kasmir, 2014:35).

Sumber penghasilan terbesar sebuah usaha bank berasal dari kontribusi banyaknya jumlah pemberian kredit yang tersalurkan. Bank di Indonesia masih menggunakan sektor bisnis perkreditan sebagai sumber utama penghasilan. Nilai margin pendapatan yang baik dapat diperoleh melalui pengelolaan manajemen dengan efektif dan efisien (Veithzal, 2012:197). Sebagai lembaga intermediary, bank harus mampu mengelola ketersediaan modal dan aset likuid yang dimiliki agar tidak terjadi kekurangan dana dalam menjalankan kegiatan bisnisnya. Kecukupan modal dan tingkat likuiditas bank menjadi perhatian penting karena akan berpengaruh terhadap kegiatan operasional suatu bank (Riyadi, 2006). Kelancaran bisnis operasional bank dapat dilihat dari seberapa besar kemampuan bank dalam menyalurkan kredit dengan meminimalisir berbagai macam risiko yang dihadapi.

Kesehatan bank dapat dilihat melalui kecukupan modal bank yang diukur melalui CAR yaitu membandingkan besarnya modal dengan aktiva tertimbang menurut risiko. Modal sendiri merupakan dana pihak I yang digunakan bank untuk mengcover risiko. Risiko yang dimaksud adalah risiko kredit.

Berdasarkan Peraturan Bank Indonesia, bank harus memiliki nilai minimum CAR sebesar $8 \%$. Kecukupan modal diperlukan apabila di masa mendatang terdapat kredit macet yang akan menurunkan nilai aktiva maka yang berkurang pada sisi pasiva adalah modal bank itu sendiri. Modal bank akan terkikis dikarenakan tidak mungkin pihak bank akan mengurangi dana pihak ketiga yang diperoleh dari nasabah. Pihak bank harus mengurangi modal sendiri daripada dana pihak ketiga. Apabila pihak bank mengurangi dana pihak ketiga maka para deposan akan menjadi tidak percaya terhadap bank tersebut. Dari sudut pandang deposan, bank dinilai tidak mampu untuk mengelola risiko yang dihadapi dan deposan akan merugi dikarenakan menurunnya nilai simpanan mereka. Apabila bank memiliki kecukupan modal melebihi ketentuan yang disyaratkan maka bank dinilai akan lebih mampu untuk menghadapi risiko kredit.

Pada perusahaan industri dan perdagangan barang likuiditas dihitung melalui besarnya current ratio yaitu perbandingan aset likuid dengan utang jangka pendek. Besarnya current ratio belum ada suatu kesepakatan/ketetapan yang pasti akan tetapi sebaiknya di atas $100 \%$. Berbeda dengan kondisi keuangan yang ada di perbankan, bank dikatakan likuid apabila memiliki kemampuan menyediakan uang tunai dengan biaya rendah dan tidak mengakibatkan kerugian (Pandia, 2012:112).

Tingkat likuiditas dapat diukur melalui rasio likuiditas. Berdasarkan Ikatan Bankir Indonesia 
(2016:54) rasio likuiditas merupakan perbandingan dari aset lancar dan total aset. Bank yang sehat memiliki likuiditas yang baik. Likuiditas merupakan kemampuan bank dalam menyediakan dana likuid yang dapat digunakan untuk memperlancar kegiatan bisnis perbankan dan memenuhi semua kewajiban yang dimiliki (Hasibuan, 2015:94). Menurut (Latumaerissa, 2014:88) likuiditas menunjukkan kompetensi pengelolaan dana dalam memenuhi kewajibannya.

Demi mengawasi dan memelihara kelancaran operasional bisnisnya, bank wajib menjaga dan mengelola likuiditas yang dimiliki. Fungsi likuiditas digunakan dalam kegiatan transaksi bisnis harian, menyediakan dana secara cepat ketika kondisi mendesak dan mampu memberikan dana ketika terdapat permintaan kredit oleh debitur (Veithzal, 2012:147). Likuiditas juga menunjukkan keahlian bank untuk membiayai pertumbuhan aset dan memenuhi kewajibannya. Menurut (Darmawi, 2014:57)bank yang mengelola likuiditas dengan baik akan memiliki kemampuan lebih dalam menyediakan dana guna memenuhi permintaan nasabah akan pinjaman serta mampu untuk memenuhi kewajiban kepada para deposan jika sewaktu-waktu melakukan penarikan dana.

Mempertahankan kualitas kredit merupakan hal sangat penting dalam memperoleh laba. Perlu adanya analisis terhadap calon debitur sehingga kredit yang diberikan tergolong sehat dan lancar. Pemberian kredit tanpa mempertimbangkan tingkat kualitas kredit dapat menyebabkan kerugian di masa depan (Darmawi, 2014:126).

Menurut Ikatan Bankir Indonesia (2016:36) kualitas kredit dapat diukur menggunakan rasio non performing loan (NPL) yang didefinisikan sebagai perbandingan antara total kredit bermasalah dengan total pinjaman yang disalurkan. Semakin besar rasio ini, semakin besar pula risiko kemungkinan tidak tertagihnya kredit yang diberikan.

Menurut Peraturan Bank Indonesia nilai NPL maksimal adalah 5\%. Jika lebih dari ketentuan yang disyaratkan maka akan dikategorikan menjadi bank yang tidak sehat. NPL merefleksikan kesehatan bank melalui besarnya kredit bermasalah. Semakin besar kredit bermasalah menyebabkan tidak tertagihnya pinjaman dan berdampak pada kerugian bank. Kredit bermasalah akan menurunkan nilai aktiva yang dimiliki sehingga mengakibatkan terkikisnya modal bank. Perlu adanya suntikan modal yang lebih apabila nilai kredit bermasalah menjadi semakin tinggi nilainya guna menghadapi risiko kredit yang ditanggung atas investasi pada aktiva yang berisiko (Riyadi, 2006:161).

Permodalan merupakan bagian dari hal yang sangat krusial bagi sebuah bank karena kesehatan dan keamanan bank dinilai dari kecukupan modal yang dimiliki. Besar kecilnya modal menunjukkan tingkat kemampuan bank untuk membiayai aset yang mengandung risiko (Pandia, 2012:28). Bank yang memiliki modal yang cukup akan lebih mampu menutupi nilai aset yang menurun sebagai akibat dari adanya kerugian bank. Penurunan laba perbankan terjadi karena besarnya kerugian ditanggung oleh bank yang disebabkan investasi pada aktiva berisiko (Latumaerissa, 2014:60).

Modal bank digunakan sebagai penyangga kegiatan operasional bank terhadap kemungkinan terjadinya kerugian dari timbulnya kredit macet. Semakin besar modal mengindikasikan bahwa bank tersebut semakin sehat permodalannya. Bank yang memiliki modal yang tinggi akan lebih mampu mengantisipasi kerugian yang diakibatkan oleh bertambahnya jumlah penyaluran kredit. Penelitian yang dilakukan oleh Kim dan Sohn (2017), Berrospide dan Edge (2010) serta Gambacorta dan Mistrulli (2004) menunjukkan bahwa capital adequacy ratio (CAR) berpengaruh positif signifikan terhadap peningkatan kredit. Semakin besar jumlah modal maka semakin tinggi kemampuan finansial dalam mengantisipasi munculnya kerugiankerugian yang disebabkan oleh banyaknya jumlah kredit yang diberikan kepada nasabah.

Modal bank memiliki dampak secara psikologis dalam peningkatan kepercayaan diri perbankan dalam memberikan kredit. Hal tersebut timbul karena bank memiliki kemampuan lebih dalam mengatasi risiko kredit macet yang mungkin terjadi di masa mendatang akibat dari investasi pada aset berisiko.

Widiarti, Siregar, dan Andati (2015) berpendapat bahwa modal bank memiliki pengaruh positif signifikan dengan tingkat efisiensi bank. Menurut Satria dan Subegti (2010)semakin tinggi kecukupan modal bank di atas kriteria yang disyaratkan oleh bank sentral maka kredit yang diberikan akan meningkat karena modal bank yang cukup dan melebihi ketentuan regulasi yang telah ditetapkan menjadi syarat penting dalam mendukung ekspansi kredit yang lebih besar. Meydianawathi (2007) berpendapat bahwa modal yang besar merefleksikan stabilnya kecukupan modal dan rendahnya risiko kredit. 
$\mathrm{H}_{1}$ : Modal bank berpengaruh positif terhadap pertumbuhan kredit.

Bank yang memiliki modal yang besar akan jauh lebih mampu memberikan kredit dalam jumlah yang lebih banyak ketika bank memiliki tingkat likuiditas yang tinggi (Kim dan Sohn, 2017). Menurut (Darmawi, 2014:57) bank yang mengelola likuiditas dengan baik akan memiliki kemampuan lebih dalam menyediakan dana guna memenuhi permintaan nasabah akan pinjaman serta mampu untuk memenuhi kewajiban kepada para deposan jika sewaktu-waktu melakukan penarikan dana.

Bank dikatakan sebagai bank sehat apabila berhasil memenuhi persyaratan Bank Indonesia (Pandia, 2012:3). Masalah likuiditas timbul apabila terjadi pengaliran kredit berlebihan yang diiringi oleh tidak stabilnya liabilitas (Darmawi, 2014:57). Bank memerlukan persediaan dana dalam menjalankan operasional bisnisnya. Fluktuasi persediaan dana bergantung pada berubahnya permintaan kredit dan simpanan deposan. Gerak perekonomian memengaruhi jumlah deposit dan penyaluran kredit. Manajemen perencanaan likuiditas merupakan salah satu fokus utama yang harus dilakukan dalam rangka menjaga kestabilan ketersediaan dana.

Bank yang mengelola tingkat likuiditasnya dengan baik akan memiliki kemampuan menyalurkan kredit dalam jumlah yang lebih banyak karena bank memiliki dana likuid yang besar sehingga lebih mampu memenuhi permintaan kredit dari nasabah (debitur). Hasil penelitian Moussa dan Chedia (2016) membuktikan bahwa likuiditas aset tidak memiliki pengaruh signifikan terhadap pertumbuhan kredit di negara Tunisia. Penelitian lain yang dilakukan oleh Kim dan Sohn (2017) menunjukkan bahwa efek moderasi tingkat likuiditas pada pengaruh modal bank terhadap pertumbuhan kredit berpengaruh positif signifikan pada ukuran bank besar.

$\mathrm{H}_{2}$ : Likuiditas bank memoderasi pengaruh modal bank terhadap pertumbuhan kredit.

Bank yang memiliki modal yang tinggi akan menjadi rendah tingkat penyaluran pinjamannya dikarenakan tingginya kredit bermasalah yang ditunjukkan dengan semakin besarnya nilai dari non performing loan (NPL). NPL menunjukkan kualitas kredit terkait dengan risiko kegagalan pembayaran (default risk). NPL merefleksikan kesehatan bank melalui besarnya kredit bermasalah. Semakin besar kredit bermasalah menyebabkan tidak tertagihnya pinjaman dan berdampak pada kerugian bank.

Kredit bermasalah akan menurunkan nilai aktiva yang dimiliki sehingga mengakibatkan terkikisnya modal bank. Perlu adanya suntikan modal yang lebih apabila nilai kredit bermasalah menjadi semakin tinggi nilainya guna menghadapi risiko kredit yang ditanggung atas investasi pada aktiva yang berisiko (Riyadi, 2006:161). Ketika bank memiliki NPL yang tinggi maka bank lebih cenderung untuk menahan pemberian kredit guna mengurangi risiko kredit atas pinjaman yang diberikan. Bank yang memiliki banyak kredit bermasalah akan memelihara capital adequacy ratio yang dimiliki agar mampu untuk menutupi penurunan nilai aktiva akibat investasi pada aset berisiko yang menyebabkan timbulnya kerugian bank.

Penelitian Satria dan Subegti (2010), Yuwono dan Meiranto (2012), Dharma (2015) dan Sania (2016) menunjukkan NPL memiliki pengaruh tidak signifikan terhadap pemberian kredit perbankan. Faktor penyebab variabel NPL tidak berpengaruh secara signifikan disebabkan adanya regulasi dari Bank Indonesia yang mengatur NPL tidak melebihi di atas 5\%. Regulasi tersebut mewajibkan agar masing-masing bank mampu menekan tingkat NPL agar tetap berada pada angka di bawah 5\%. Dengan demikian dapat disimpulkan bahwa fluktuasi besar kecilnya NPL selama masih di bawah 5\%, bank masih berada dalam kategori sehat dan dianggap mampu menyalurkan lebih banyak kredit. Dalam beberapa hasil penelitian yang telah dilakukan terdapat hasil yang tidak signifikan menyebabkan peneliti tertarik untuk menjadikan kualitas kredit yang diproksikan dengan NPL sebagai variabel moderasi pada pengaruh modal bank terhadap pertumbuhan kredit. $\mathrm{H}_{3}$ : NPL memoderasi pengaruh modal bank terhadap pertumbuhan kredit

\section{METODE PENELITIAN}

Pendekatan kuantitatif digunakan dalam penelitian karena data yang disajikan dalam bentuk angka/nominal dengan pengukuran secara sistematis melalui purposive sampling pada 40 bank yang terdaftar di Bursa Efek Indonesia periode 2010-2016. Pengukuran dilakukan berdasarkan laporan keuangan perusahaan untuk mencari pengaruh modal bank terhadap pertumbuhan kredit yang dimoderasi dengan tingkat likuiditas dan NPL bank. Penelitian yang dilakukan untuk menguji hipotesis dengan alat statistik dan data yang terukur sehingga 
menghasilkan inferensi secara general. Penelitian ini menggunakan IBM SPSS Statistic 25 for Windows sebagai alat bantu statistik.

Variabel dependen menggunakan pertumbuhan kredit dihitung dengan rumus:

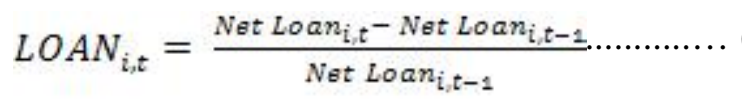

Variabel independen menggunakan modal bank dihitung dengan rumus:

$$
C A R_{i, t}=\frac{\text { Bank Capital }_{i, t}}{\text { Risk Weighted } \text { Assets }_{i, t}}
$$

Variabel moderasi menggunakan likuiditas dan NPL bank dihitung dengan rumus:

$$
\begin{aligned}
L I Q_{i, t} & =\frac{\text { Total Liquid Assets }_{i, t}}{\text { Total Assets }_{i, t}} \ldots . . . . . \\
N P L_{i, t} & =\frac{\text { Non Performing Loans } i, t}{\text { Total Loans }}, \ldots
\end{aligned}
$$

Variabel kontrol menggunakan ukuran perusahaan dihitung dengan rumus:

$\operatorname{SIZE}_{i, t}=\log$ Total Assets $_{i, t}$

\section{Model Analisis}

Model analisis dalam penelitian menggunakan analisis linear berganda dan moderated regression analysis (MRA). Pengujian model analisis linear berganda dilakukan untuk mengetahui pengaruh modal bank terhadap pertumbuhan kredit yang dikontrol menggunakan ukuran perusahaan. Pengujian model moderated regression analysis (MRA) dilakukan untuk mengetahui pengaruh modal bank terhadap pertumbuhan kredit yang dimoderasi dengan tingkat likuiditas dan NPL serta dikontrol dengan ukuran perusahaan. Model analisis dalam penelitian ini dirumuskan sebagai berikut:

$$
\begin{aligned}
& \text { Model analisis } 1 \text { (tanpa moderasi) } \\
& L \quad i, t=\beta_{0}+\beta_{1} C \quad i, t-1+\beta_{2} L_{i, t-1}+ \\
& \beta_{3}(C \quad * L \quad)_{i, t-1}+\beta_{4} S \quad i, t-1+e_{i, t}
\end{aligned}
$$

Model analisis 2(setelah dimoderasi tingkat likuiditas bank)

$$
\begin{aligned}
& L \quad i, t=\beta_{0}+\beta_{1} C_{i, t-1}+\beta_{2} N_{i, t-1}+
\end{aligned}
$$

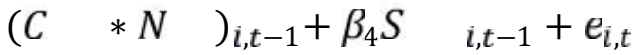

Model analisis 3 (setelah dimoderasi NPL)

$$
L O A N_{i, t}=\beta_{0}+\beta_{1} C A R_{i, t-1}+\beta_{2} S_{I Z E_{i, t-1}}+e_{i, t}
$$

Keterangan :

$\beta_{0} \quad$ : Konstanta

$\beta_{1} \beta_{2} \beta_{3} \beta_{4} \quad$ : Koefisien Regresi

LOAN $_{i, t} \quad$ : Persentase tingkat pertumbuhan kredit bank i pada periode ke $\mathrm{t}$

CAR $_{i, t-1} \quad$ : Capital Adequacy Ratio bank i pada periode ke $\mathrm{t}-1$

$L I Q_{i, t-1} \quad:$ Rasio likuiditas bank i periode ke $\mathrm{t}-1$

$(C A R * L I Q)_{i, t-1}$ : Interaksi antara modal dan tingkat likuiditas bank i periode ke $\mathrm{t}-1$

NPL ${ }_{i, t-1} \quad$ : Non Performing Loan bank i pada periode $\mathrm{t}-1$

$\left(C A R^{*} N P L\right)_{i, t-1}$ : Interaksi antara modal dan NPL bank i periode ke $\mathrm{t}-1$

SIZE $_{i, t-1} \quad$ : Ukuran perusahaan bank i pada periode $\mathrm{t}-1$

$\varepsilon i, t \quad:$ Error atau nilai residu

\section{HASIL DAN PEMBAHASAN}

Penelitian menggunakan data sekunder berjumlah 40 bank konvensional yang didapat melalui laporan keuangan yang terdaftar di Bursa Efek Indonesia periode 2010-2016 pada situs www.idx.co.id.

Tabel 1. Statistik Deskriptif

\begin{tabular}{lccccc}
\hline Variabel & N & Minimum & Maximum & Mean & $\begin{array}{c}\text { Standard } \\
\text { Deviation }\end{array}$ \\
\hline LOAN & 137 & -0.18 & 1.55 & 0.17 & 0.21 \\
CAR & 137 & 0.11 & 0.87 & 0.19 & 0.10 \\
LIQ & 137 & 0.11 & 0.75 & 0.28 & 0.11 \\
CAR*LIQ & 137 & 0.02 & 0.44 & 0.06 & 0.06 \\
NPL & 137 & 0.00 & 0.09 & 0.02 & 0.01 \\
CAR*NPL & 137 & 0.00 & 0.02 & 0.00 & 0.00 \\
SIZE & 137 & 11.40 & 14.91 & 13.43 & 0.86 \\
\hline
\end{tabular}

Sumber: Hasil Olah Data IBM SPSS Statistic 25 for Windows 
Variabel pertumbuhan kredit perbankan memiliki rata-rata sebesar 0,17 . Nilai minimum pertumbuhan kredit perbankan sebesar $-0,18$ menunjukkan nilai terendah pertumbuhan kredit yang dilakukan oleh bank. Nilai maksimum pertumbuhan kredit sebesar 1,55 menunjukkan nilai tertinggi pertumbuhan kredit yang dilakukan oleh bank. Variabel modal bank memiliki rata-rata sebesar 0,19 yang menunjukkan bahwa rata-rata bank di
Indonesia termasuk dalam kategori bank sehat karena memiliki CAR lebih dari 8\%. Variabel tingkat likuiditas bank memiliki rata-rata sebesar 0,28. Variabel kualitas kredit (NPL) memiliki rata-rata sebesar 0,02 kurang dari 5\% yang menunjukkan bahwa rata-rata bank di Indonesia memiliki kualitas kredit yang baik. Variabel ukuran perusahaan memiliki rata-rata sebesar 13,43.

Tabel 2. Matriks Korelasi

\begin{tabular}{|c|c|c|c|c|c|c|}
\hline & & 1 & 2 & 3 & 4 & 5 \\
\hline 1 & $\begin{array}{l}\text { LOA } \\
\mathrm{N}\end{array}$ & - & & & & \\
\hline 2 & CAR & 0.57 & - & & & \\
\hline 3 & LIQ & 0.45 & 0.42 & - & & \\
\hline 4 & NPL & -0.22 & $\overline{-}$ & $\begin{array}{c}- \\
0.05\end{array}$ & - & \\
\hline 5 & SIZE & -0.37 & $\overline{-}$ & $\begin{array}{c}- \\
0.53\end{array}$ & $\begin{array}{c}0.0 \\
6\end{array}$ & - \\
\hline
\end{tabular}

Sumber : Hasil Olah Data IBM SPSS Statistic 25 for Windows

$\mathrm{N}=137$, Huruf Tebal menunjukkan korelasi signifikan pada level 5\%

Hasil pada Tabel 3 menunjukkan bahwa modal bank berpengaruh positif signifikan terhadap pertumbuhan kredit baik sebelum dimoderasi dan setelah dimoderasi dengan tingkat likuiditas bank dan NPL. Semakin tinggi modal bank semakin besar pula peningkatan jumlah kredit. Hasil penelitian ini searah dengan penelitian yang dilakukan oleh Kim dan Sohn (2017), Berrospide dan Edge (2010), Gambacorta dan Mistrulli (2004), Satria dan Subegti (2010) serta Meydianawathi (2007) yang menyatakan bahwa modal bank berpengaruh positif signifikan terhadap penyaluran kredit perbankan.

Berdasarkan Peraturan Bank Indonesia, bank harus memiliki nilai minimum CAR sebesar $8 \%$. Kecukupan modal diperlukan apabila di masa mendatang terdapat kredit macet yang akan menurunkan nilai aktiva maka yang berkurang pada sisi pasiva adalah modal bank itu sendiri. Modal bank akan terkikis dikarenakan tidak mungkin pihak bank akan mengurangi dana pihak ketiga yang diperoleh dari nasabah. Pihak bank harus mengurangi modal sendiri daripada dana pihak ketiga. Apabila pihak bank mengurangi dana pihak ketiga maka para deposan akan menjadi tidak percaya terhadap bank tersebut. Dari sudut pandang deposan, bank dinilai tidak mampu untuk mengelola risiko yang dihadapi dan deposan akan merugi dikarenakan menurunnya nilai simpanan mereka. Apabila bank memiliki kecukupan modal melebihi ketentuan yang disyaratkan maka bank dinilai akan lebih mampu untuk menghadapi risiko kredit.

Permodalan merupakan bagian dari hal yang sangat krusial bagi sebuah bank karena kesehatan dan keamanan bank dinilai dari kecukupan modal yang dimiliki. Besar kecilnya modal menunjukkan tingkat kemampuan bank untuk membiayai aset yang mengandung risiko (Pandia, 2012:28). Bank yang memiliki modal yang cukup akan lebih mampu menutupi nilai aset yang menurun yang diakibatkan dari kerugian-kerugian bank. Penurunan laba perbankan terjadi karena besarnya kerugian ditanggung oleh bank yang disebabkan investasi pada aktiva berisiko (Latumaerissa, 2014:60).

Modal bank digunakan sebagai penyangga kegiatan operasional bank terhadap kemungkinan terjadinya kerugian dari timbulnya kredit macet. Semakin besar modal mengindikasikan bahwa bank tersebut semakin sehat permodalannya. Bank yang memiliki modal yang tinggi akan lebih mampu mengantisipasi kerugian yang diakibatkan oleh bertambahnya jumlah penyaluran kredit. Dengan antisipasi kerugian yang lebih baik maka bank akan lebih berani untuk menyalurkan kredit dalam jumlah yang lebih besar.

Hasil moderasi pada Tabel 3, Variabel moderasi tingkat likuiditas bank memiliki nilai positif yang signifikan. Likuiditas bank memperkuat pengaruh positif modal bank terhadap pertumbuhan kredit. Hal 
Tabel 3. Hasil Regresi Linear Berganda dan Moderated Regression Analysis

\begin{tabular}{|c|c|c|c|c|}
\hline \multirow{2}{*}{$\begin{array}{l}\text { Variabel } \\
\text { Dependen: } \\
\text { Tipe Regresi: }\end{array}$} & \multicolumn{4}{|c|}{ LOAN GROWTH } \\
\hline & OLS & OLS & OLS & OLS \\
\hline Intercept & $\begin{array}{r}* * *-0.701 \\
(\mathbf{0 . 0 0 3})\end{array}$ & $\begin{array}{r}* * *-0.881 \\
(0.002)\end{array}$ & $\begin{array}{r}* 0.730 \\
(0.061)\end{array}$ & $\begin{array}{r}* * 0.767 \\
(0.049)\end{array}$ \\
\hline$C A R$ & $\begin{array}{r}* * * 1.749 \\
(0.000)\end{array}$ & $\begin{array}{l}* 0.897 \\
(\mathbf{0 . 0 6 6 )}\end{array}$ & $\begin{array}{r}* * * 1.216 \\
(0.000)\end{array}$ & $\begin{array}{r}* * * 1.379 \\
(\mathbf{0 . 0 0 0})\end{array}$ \\
\hline$L I Q$ & & $\begin{array}{r}0.007 \\
(0.979)\end{array}$ & & \\
\hline$C A R \times L I Q$ & & $\begin{array}{l}* 1.760 \\
(0.098)\end{array}$ & & \\
\hline$N P L$ & & & & $\begin{array}{r}2.791 \\
(0.106)\end{array}$ \\
\hline$C A R \times N P L$ & & & & $\begin{array}{r}* *-24.838 \\
(0.020)\end{array}$ \\
\hline SIZE & $\begin{array}{r}* * 0.040 \\
(\mathbf{0 . 0 1 4})\end{array}$ & $\begin{array}{r}* * * 0.058 \\
(\mathbf{0 . 0 0 1 )}\end{array}$ & $\begin{array}{r}* *_{-} \mathbf{0 . 0 5 7} \\
(\mathbf{0 . 0 4 2})\end{array}$ & $\begin{array}{r}* *_{-} \mathbf{0 . 0 5 9} \\
(\mathbf{0 . 0 3 3 )}\end{array}$ \\
\hline Observations & 137 & 137 & 137 & 137 \\
\hline R-Squared & 0.574 & 0.607 & 0.342 & 0.372 \\
\hline $\begin{array}{l}\text { F-Statistic } \\
\text { Sig }\end{array}$ & $\begin{array}{r}* * * 90.433 \\
(0.000)\end{array}$ & $\begin{array}{r}* * * 50.999 \\
(0.000)\end{array}$ & $\begin{array}{r}* * * 34.755 \\
(\mathbf{0 . 0 0 0})\end{array}$ & $\begin{array}{r}* * * 19.530 \\
(0.000)\end{array}$ \\
\hline
\end{tabular}

\footnotetext{
Sumber: Hasil Olah Data IBM SPSS Statistic 25 for Windows

*** Signifikan pada level $1 \%$

** Signifikan pada level 5\%

* Signifikan pada level $10 \%$
}

tersebut menunjukkan bahwa pengaruh positif modal bank terhadap pertumbuhan kredit akan menjadi semakin kuat ketika bank memiliki tingkat likuiditas yang besar. Bank yang memiliki modal yang tinggi akan jauh lebih mampu menyalurkan kredit dalam jumlah yang lebih banyak ketika bank memiliki tingkat likuiditas yang tinggi (Kim dan Sohn, 2017).

Bank yang mengelola tingkat likuiditasnya dengan baik akan memiliki kemampuan menyalurkan kredit dalam jumlah yang lebih banyak karena bank memiliki dana likuid yang besar sehingga lebih mampu memenuhi permintaan kredit dari nasabah (debitur). Hasil penelitian Moussa dan Chedia (2016) membuktikan bahwa likuiditas aset tidak memiliki pengaruh signifikan terhadap pertumbuhan kredit di negara Tunisia. Penelitian lain yang dilakukan oleh Kim dan Sohn (2017) menunjukkan bahwa efek moderasi tingkat likuiditas pada pengaruh modal bank terhadap pertumbuhan kredit berpengaruh positif signifikan pada ukuran bank besar. Dari hasil tersebut maka dalam penelitian ini tingkat likuiditas dijadikan sebagai variabel moderasi.

Bank dikatakan sebagai bank sehat apabila berhasil memenuhi persyaratan Bank Indonesia (Pandia, 2012:3). Masalah likuiditas timbul apabila terjadi pengaliran kredit berlebihan yang diiringi oleh tidak stabilnya liabilitas (Darmawi, 2014:57) Bank memerlukan persediaan dana dalam menjalankan operasional bisnisnya. Fluktuasi persediaan dana bergantung pada berubahnya permintaan kredit dan simpanan deposan. Gerak perekonomian memengaruhi jumlah deposit dan penyaluran kredit. Manajemen perencanaan likuiditas salah satu fokus utama dilakukan dalam rangka menjaga kestabilan ketersediaan dana. Latumaerissa (2014:88) berpendapat bahwa likuiditas menunjukkan kompetensi pengelolaan dana dalam memenuhi kewajibannya. Bank yang mengelola likuiditas dengan baik akan memiliki kemampuan lebih dalam menyediakan dana guna memenuhi permintaan nasabah akan pinjaman serta mampu untuk memenuhi kewajiban kepada para deposan jika sewaktu-waktu melakukan penarikan dana. Tingkat likuiditas dapat diukur melalui rasio likuiditas.

Hasil tersebut diperkuat dengan fenomena yang ada di Indonesia. Berdasarkan Gambar 1. fluktuasi CAR selalu diikuti dengan pergerakan likuiditas yang hampir sejajar. Pergerakan dua variabel tersebut selalu berjalan beriringan di setiap periode waktu. Pada Gambar 2. pergerakan pertumbuhan kredit 
yang disalurkan dipengaruhi oleh nilai CAR pada periode sebelumnya. Hal ini dibuktikan dengan pergerakan CAR memiliki fluktuasi yang searah terhadap pertumbuhan kredit perbankan pada periode berikutnya. Fenomena tersebut menunjukkan bahwa besarnya modal bank memengaruhi jumlah kredit yang disalurkan dan tingkat likuiditas memperkuat pengaruh modal bank terhadap pertumbuhan kredit perbankan yang ada di Indonesia.

Variabel moderasi NPL memiliki nilai negatif signifikan. Hasil regresi moderasi NPL bank menunjukkan bahwa NPL memperlemah pengaruh positif modal bank terhadap pertumbuhan kredit. Bank yang memiliki modal yang tinggi akan menahan jumlah kredit yang disalurkan ketika bank memiliki tingkat kualitas kredit yang rendah.

Bank yang memiliki modal yang tinggi akan menjadi rendah tingkat penyaluran pinjamannya dikarenakan tingginya kredit bermasalah yang ditunjukkan dengan semakin besarnya nilai dari non performing loan (NPL). Ketika bank memiliki NPL yang tinggi maka bank lebih cenderung untuk menahan pemberian kredit guna mengurangi risiko kredit atas pinjaman yang diberikan.

Mempertahankan kualitas kredit merupakan hal sangat penting dalam memperoleh laba. Perlu adanya analisis terhadap calon debitur sehingga kredit yang diberikan tergolong sehat dan lancar. Pemberian kredit tanpa mempertimbangkan tingkat kualitas kredit dapat menyebabkan kerugian di masa depan (Darmawi, 2014:126).

Menurut Peraturan Bank Indonesia nilai NPL maksimal adalah 5\%. Jika lebih dari ketentuan yang disyaratkan maka akan dikategorikan menjadi bank yang tidak sehat. NPL merefleksikan kesehatan bank melalui besarnya kredit bermasalah. Semakin besar kredit bermasalah menyebabkan tidak tertagihnya pinjaman dan berdampak pada kerugian bank.

Kredit bermasalah akan menurunkan nilai aktiva yang dimiliki sehingga mengakibatkan terkikisnya modal bank. Perlu adanya suntikan modal yang lebih apabila nilai kredit bermasalah menjadi semakin tinggi nilainya guna menghadapi risiko kredit yang ditanggung atas investasi pada aktiva yang berisiko (Riyadi, 2006:161). Ketika bank memiliki NPL yang tinggi maka bank lebih cenderung untuk menahan pemberian kredit guna mengurangi risiko kredit atas pinjaman yang diberikan. Bank yang memiliki banyak kredit bermasalah akan memelihara capital adequacy ratioyang dimiliki agar mampu untuk menutupi penurunan nilai aktiva akibat investasi pada aset berisiko yang menyebabkan timbulnya kerugian bank.

Penelitian yang dilakukan oleh Satria dan Subegti (2010), Yuwono dan Meiranto (2012), Dharma (2015) dan Sania (2016) menunjukkan bahwa NPL berpengaruh tidak signifikan terhadap penyaluran kredit perbankan. Faktor yang menyebabkan variabel NPL tidak berpengaruh secara signifikan disebabkan adanya regulasi dari Bank Indonesia yang mengatur ketentuan besaran NPL yakni nilai NPL tidak boleh berada di atas 5\%. Regulasi tersebut mewajibkan agar masing-masing bank mampu menekan tingkat NPL agar tetap berada pada angka di bawah 5\%. Dengan demikian dapat disimpulkan bahwa fluktuasi besar kecilnya NPL selama masih di bawah 5\%, bank masih berada dalam kategori sehat dan dianggap mampu menyalurkan lebih banyak kredit.

Pertumbuhan kredit tidak hanya dipengaruhi oleh modal bank, tingkat likuiditas dan NPL tetapi juga dipengaruhi oleh ukuran perusahaan. Berdasarkan hasil analisis regresi, variabel ukuran perusahaan dapat berpengaruh positif dan negatif signifikan terhadap pertumbuhan kredit.

Bank kecil memiliki rasio pertumbuhan kredit lebih besar dikarenakan berada dalam tahap pertumbuhan. Dalam tahap ini, bank akan lebih berani untuk menyalurkan kredit dalam jumlah yang besar supaya mampu untuk bersaing dengan para kompetitor dengan memberikan insentif bunga yang lebih tinggi. Hal tersebut akan berdampak pada semakin besarnya kredit yang disalurkan pada saat ini dibanding dengan tahun sebelumnya (Kim dan Sohn, 2017). Fenomena tersebut menyebabkan bank kecil memiliki pertumbuhan kredit yang begitu tinggi.

Di sisi lain, bank-bank besar memiliki manajemen modal dan likuiditas yang lebih baik. Bank-bank besar memiliki insentif lebih banyak untuk mengambil risiko lebih tinggi dalam upaya meningkatkan jumlah penyaluran kredit. Bank dengan aset yang besar memiliki infrastruktur berupa sumber daya, teknologi informasi, dan struktur organisasi yang memadai dalam mendukung kegiatan operasional bank. Bank besar juga didukung dengan jaringan kantor yang tersebar di seluruh wilayah dan memiliki produk perbankan yang beragam sehingga bank tersebut lebih mampu untuk menyalurkan kredit dalam jumlah yang lebih besar dibanding dengan bank kecil (Berrospide dan Edge, 2010).

\section{SIMPULAN DAN SARAN}

Hasil penelitian menunjukkan bahwa modal bank berpengaruh positif terhadap pertumbuhan 
kredit. Variabel tingkat likuiditas bank memperkuat pengaruh positif modal bank terhadap pertumbuhan kredit dan variabel moderasi NPL memperlemah pengaruh positif modal bank terhadap pertumbuhan kredit.

Sumber penghasilan terbesar sebuah usaha bank berasal dari kontribusi banyaknya jumlah pemberian kredit yang tersalurkan. Bank di Indonesia masih menggunakan sektor bisnis perkreditan sebagai sumber utama penghasilan. Nilai margin pendapatan yang baik dapat diperoleh melalui pengelolaan manajemen dengan efektif dan efisien. Sebagai lembaga intermediary, bank harus mampu mengelola ketersediaan modal dan aset likuid yang dimiliki agar tidak terjadi kekurangan dana dalam menjalankan kegiatan bisnisnya. Kecukupan modal dan tingkat likuiditas bank menjadi perhatian penting karena akan berpengaruh terhadap kegiatan operasional suatu bank.

Manajemen bank perlu memperhatikan modal, tingkat likuiditas dan NPL untuk mengukur kemampuan bank dalam memberikan kredit. Bank yang ingin menyalurkan kreditnya perlu memperhatikan ketiga variabel tersebut. Dengan dipenuhinya hal ini maka bank memiliki kemampuan lebih besar dalam menyalurkan kredit. Dengan menganalisis modal, tingkat likuiditas dan NPL dengan tepat maka besar kemungkinan bank dalam meningkatkan jumlah penyaluran kredit akan menjadi lebih baik. Investor dapat menggunakan acuan modal, tingkat likuiditas dan NPL dalam menilai kesehatan bank. Informasi tersebut dapat digunakan investor sebagai acuan dalam menentukan pilihan investasinya pada saham perbankan.

Bank yang sehat dilihat dari tingkat likuiditas yang terpelihara dengan baik, tercukupinya modal dan kualitas kredit yang tersalurkan dengan baik. Likuiditas yang terjaga baik memiliki aset lancar yang cukup sehingga memungkinkan bank dapat memenuhi secara cepat penarikan deposannya (demand deposit) dan mampu menyediakan dana ketika terdapat permintaan kredit oleh debitur. Pengalokasian dana yang tepat, sehat dan profitable menjadi salah satu sumber pendapatan optimal bank dengan rendahnya tingkat kredit yang tidak tersalurkan dengan baik (non performing loan).

Penelitian lebih lanjut akan menjadi semakin baik apabila membagi sampel yang diteliti berdasarkan ukuran bank yaitu bank besar, bank medium dan bank kecil. Saran bagi peneliti selanjutnya sebaiknya menambahkan faktor-faktor yang memengaruhi peningkatan kredit dari sisi eksternal perbankan (seperti faktor makroekonomi) sehingga analisis dapat memberikan inferensi yang lebih akurat.

\section{REFERENSI}

Board, F. R., Berrospide, J. M., \& Edge, R. M. (2010). Divisions of Research \& Statistics and Monetary Affairs The Effects of Bank Capital on Lending/: What Do We Know , and What Does it Mean/? The effects of bank capital on lending/: What do we know, and what does it mean/ ?. Finance and Economics.

Darmawi, H. (2014). Manajemen Perbankan. Jakarta: PT Bumi Aksara.

Dharma, R. (2015). Analisis Faktor-Faktor Yang Mempengaruhi Kebijakan Penyaluran Kredit Perbankan ( Studi Kasus Pada Bank Umum Di Indonesia Periode Tahun 2008-2012). Jurnal EKOBISTEK Fakultas Ekonomi, 4(2), 37-54.

Gambacorta, L., \& Mistrulli, P. E. (2004). Does bank capital affect lending behavior? Journal of Financial Intermediation, 13(4), 436-457.

Hasibuan, M. (2015). Dasar-Dasar Perbankan. Jakarta: PT Bumi Aksara.

Indonesia, I. B. (2016). Tata Kelola Manajemen Risiko Perbankan. Jakarta: PT Gramedia Pustaka Utama.

Ismail. (2016). Manajemen Perbankan Dari Teori Menuju Aplikasi. Jakarta: Prenadamedia Group.

Kasmir. (2014). Dasar-Dasar Perbankan Edisi Revisi 2014. Jakarta: PT Raja Grafindo Persada.

Kim, D., \& Sohn, W. (2017). The effect of bank capital on lending: Does liquidity matter? Journal of Banking and Finance, 77, 95-107.

Latumaerissa, J. (2014). Manajemen Bank Umum. Jakarta: Mitra Wacana Media.

Meydianawathi, L. G. (2007). Analisis Perilaku Penawaran Kredit Perbankan Kepada Sektor UMKM di Indonesia (2002-2006). Buletin Studi Ekonomi, 12(2), 134-147.

Moussa, M. A. Ben, \& Chedia, H. (2016). Determinants of Bank Lending: Case of Tunisia. International Journal of Finance and Accounting, 5(1), 27-36.

Pandia, F. (2012). Manajemen Dana dan Kesehatan Bank. Jakarta: PT Rineka Cipta.

Riyadi, S. (2006). Banking Assets and Liability Management Edisi Ketiga. Jakarta: Lembaga Penerbit Fakultas Ekonomi Universitas Indonesia. 
Sania, Z. M. (2016). Pengaruh DPK, NPL dan CAR terhadap Jumlah Penyaluran Kredit Perbankan Persero. Jurnal Ilmu Dan Riset Manajemen, $5(1), 1-15$.

Satria, D., \& Subegti, R. B. (2010). Determinasi Penyaluran Kredit Bank Umum di Indonesia Periode 2006-2009. Jurnal Keuangan Dan Perbankan, 14, 415-424.

Supramono, G. (2009). Perbankan dan Masalah Kredit. Jakarta: PT Rineka Cipta.

Veithzal, R. (2012). Commercial Bank Management. Jakarta: PT Raja Grafindo Persada.

Widiarti, A. W., Siregar, H., \& Andati, T. (2015). The Determinants of Bank's Efficiency in Indonesia. Buletin Ekonomi Moneter Dan Perbankan, 18(2), 130-156.

Yuwono, F. A., \& Meiranto, W. (2012). Analisis Pengaruh Dana Pihak Ketiga, Loan To Deposit Ratio , Capital Adequacy Ratio, Non Performing Loan, Return on Assets, Dan Sertifikat Bank Indonesia. Diponegoro Journal of Accounting, 1, 1-14. 